\title{
Eco Innovations in Slovakia and Their Marketing Communication
}

\author{
Anna Zaušková, Rudolf Rybanský, Renáta Miklenčičová \\ Faculty of Mass Media Communication of University of Ss. Cyril and Methodius in Trnava, Nám. J. Herdu 2, 91701 Trnava, the \\ Slovak Republic
}

\begin{abstract}
The paper deals with measuring eco innovations and their communication from two main viewpoints. The first one refers to the standpoint of Slovak businesses towards the implemented eco innovations of their products while the second one describes the impact of product innovations on consumers' purchasing behaviour.

The first research we carried out by way of the questionnaire in course of three years (2012 to 2014) helped us to find out that all businesses having implemented their ecological innovations behave in a sustainable manner. When promoting eco innovations, they mainly make use of on-line communication, direct marketing or public relations while emphasizing environmental labelling of their eco-products. It is worth noting that they use only one communication tool, which may be considered as a gap and therefore, we assume businesses should pay more attention to implementing a larger set of tools.

In the second research, which we carried out in the year 2014, we used the questionnaire to reveal what is the influence of eco innovations of products on purchasing behaviour of customers. When evaluating the results, we discovered that Slovak respondents were aware of the products with environmental labelling. However, they show objections regarding their labelling on a product package. They also stated a low level of information, insufficient communication in the media, print or on-line communication channels. One of the solutions may be combining classic forms of marketing communication with the digital ones which are considered as more ecological and environmentally-friendly.
\end{abstract}

Index Terms - eco innovations, environmental labelling of products, marketing communication, business, consumer

\section{Introduction}

Consumer way of life, continuous acquisition of material welfare and their collection have all led to great environmental imbalance which has resulted in a present or an anticipated lack of natural resources, water, soil and air pollution or environmental pollution as such. Eco innovations represent one of the possibilities how to contribute by way of particular steps to reparation of the present conditions or even changing of human thinking.

Eco innovations can have various forms, however, as many authors may argue, their key point is a positive change to the environment. Such a change, relating to either products or business processes, is much needed these days. The definition put forward by the group of researchers from the Masstricht University headed by Arundel and Kemp [1] is often used, and that is ,the eco innovation is production, implementation or usage of products, services, business processes, hierachical structures, management or business models which are new for the company or the users and which result in lowering environmental risks, pollution or negative impact of source exploitation in comparison with the existing alternatives". OECD [2] defines eco innovations as "implementation of new or considerably improved products, processes, marketing methods, hierarchical structures or institutional structures which either intentionally or indirectly lead to improving the environment."

Creation and implementation of eco-innovative products is closely linked with their environmental labelling, serving as a basis for setting the standards of a product quality and informing a consumer on a certain quality level. In addition, they enable a consumer to evaluate and compare products in a point of sale and differentiate products of a different quality [9], [14].

As stated by Rusko [3], environmental product labelling was introduced in 1977-1978, when Germany put into practice the first eco-labelling certification programme which was centrally governed by a third independent party. The programme was successfully established in the German market conditions and as a result, other foreign businesses started applying for the eco-label "Blue Angel". Great success of this eco-labelling programme led to creation of further ecoprogrammes in other countries in the world. In 1988, Canada became the second state to implement unique product labelling. The Canadian programme was created to promote sustainable development while incorporating the aspects of environmental protection into economic decision-making. In the same year, the Scandinavian Council of Ministers in charge of consumer protection introduced the Nordic eco-labelling programme "White Swan" which became the first multinational programme. Later on, other eco-labelling programmes were launched, e.g. in 1989 in Japan, in 1991 in Austria and in 1994 the global network of environmental labelling GEN (Global Ecolabelling Network) was established. GEN is a non-profit organisation uniting within its large network national and multinational programmes from all over the world. Slovakia has been implementing the label "Environmentally friendly product" since 1997. Granting the environmental label is conditioned by verification of environmental impact in course of the whole product life cycle. The Slovak programme accepts the principle of assessment of a product life cycle. It is worth noting that the environmental label can be exclusively granted to the product which is declared as environmentally friendly in course of its whole product cycle, i.e. from raw materials through manufacturing until recycling or waste disposal. At the same time, it is important to minimise the 
negative environmental impact in each stage of a product life cycle.

In the Slovak Republic, environmental product labelling is governed by the Act № 469/2002 Coll. on environmental product labelling as further amended or modified [4]. The Act specifies the conditions and the procedure of granting and using the national environmental label "Environmentally friendly product" and the environmental label of the European Community "European Flower". The label "Environmentally friendly product" is granted to products and services which comply with the strict conditions as amended by the Regulation of the Ministry of Environment of the Slovak Republic as designed for a particular group of products. [5]

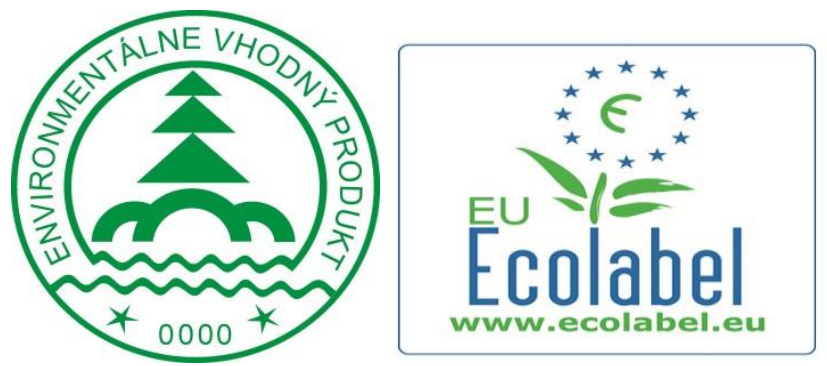

Fig. 1 Environmental product labelling in Slovakia.

\section{Eco Innovations in Slovakia}

In order to evaluate the level of eco innovations in the Slovak Republic, we have carried out two sorts of empiric research. The first one aimed at appealing to the products which had implemented eco innovations for the previous three years $(2012-2014)$ with the emphasis on marketing activities they undertook in order to promote creation and implementation of eco innovations. The second research focused mainly on assessing impact of product eco innovations on consumers' purchasing behaviour or buying habits.

\section{A. Implementation of Eco Innovations in Slovak Businesses and Their Marketing Support}

By way of a questionnaire, we addressed small and middle-sized businesses as they represent the main players in innovation business thanks to their high flexibility and adaptability to changing market conditions. We addressed 5.500 businesses, while their feedback was $80 \%$.

We found out that $53.15 \%$ of small and middle-sized businesses implemented eco innovations for a certain period of time. We tried to find the connection between sustainable behaviour of businesses on a daily basis and implementation of innovative and environmentally friendly projects. The research into these two inter-linked fields showed that $97.14 \%$ of businesses having implemented eco innovations are trying to adopt sustainable behaviour in their business. After having evaluated all the available data, we understood the finacial resources represented the greatest obstacle to eco implementation - up to $23.1 \%$. We focused on assessing the relation between gaining a competitive advantage of a company implementing an eco innovation and a consumer interest in ecological features of products, services or solutions. Even though $28.75 \%$ of businesses confirmed having implemented eco innovations in order to gain a competitive advantage, the results pointed out that $22 \%$ of consumers themselves are not as interested in specific ecological products or services as we would have anticipated. Therefore we may assume that the need for protection of nature and its resources or the environmental protection itself or lowering the negative impact of a consumer way of life are well established in the awareness of both businesses and consumers. However, they do not much reflect in purchasing behaviour or purchasing decisions. A consumer seems to be unsure whether or not to purchase an innovative product. Regarding the marketing communication of businesses [10], the results showed that the on-line communication, direct marketing, public relations and environmental product labelling belong among the most often used tools to promote eco innovations. Their percentage usage is shown in the table № 1 .

The table shows that only $54.27 \%$ of businesses having implemented eco innovations made use of marketing tools in order to promote one of the above mentioned activities. In all cases, only one marketing tool was used, which we may consider as a drawback as it is only through a sensible combination of communication tools that businesses are able to address their target consumers.

TABLE 1 Marketing communication in creation and implementation of eco innovations in Slovakia

\begin{tabular}{|l|c|}
\hline Marketing tool & {$[\%]$} \\
\hline On-line communication & $28.57 \%$ \\
\hline Direct marketing & $17.14 \%$ \\
\hline Public relations (PR) & $5.71 \%$ \\
\hline Environmental product labelling & $2.85 \%$ \\
\hline Total: & $54.27 \%$ \\
\hline
\end{tabular}

Resource: our own resources, year 2015

\section{B. Perception of Environmental Product Labelling by Slovak Consumers}

In the framework of the analysis of the current state of eco innovations in Slovakia we carried out another empiric research in 2014, the aim of which was to discover the impact of product eco innovations on consumers' purchasing behaviour. The research was again carried out by way of a questionnaire using a random sample of respondents. The overall feedback of questionnaires amounted to 1.358 questionnaire out of 1.400 pieces.

The results point to various circumstances in the field of environmental awareness of consumers. The most crucial was the fact that $69.8 \%$ of respondents declared to be interested in „ecological“ products. $79.3 \%$ of respondents referred to the Slovak product eco-labelling system as insufficient. Consumers seem to be sufficiently informed on 
environmentally-friendly products from the part of sellers or vendors.

In addition, the research pointed to great dissatisfaction with placement and content of available information on product packaging which should highlight environmental friendliness of a product through the production process or consumption. More than a half, i.e. $65.7 \%$ of consumers are not aware of or have not got in touch with environmental labelling. Some businesses do not place emphasis on product labelling, nor on a quality and origins of products their customers purchase on a daily basis. Mostly the elderly do not often understand the mere graphic symbols and as a result, they do not pay particular attention hereto. The environmental marketing communication should provide liable information on products. Moreover, it should contain objective, clear information on specific ecological characteristics and benefits of each product. On the other hand, stating a large quantity of data on packaging may lead to oversaturation with information and as a result, consumers may either overlook or merely ignore such information. Therefore, such information should be stated in a different manner (e.g. by way of a symbol, a mark or a brief piece of information).

It also emerged that $75.1 \%$ of respondents were willing to educate themselves in the environmental field in order to acquire new knowledge of basic principles of sensible exploitation of natural resources and lower consumption.

The remarkable results emerged in the questions where we were interested in the degree of respondents' knowledge of environmental labels they usually get in touch with in the Slovak market. In the first part we asked whether they had any knowledge of environmental labelling used in Slovakia, where $41.8 \%$ of them answered ,yes" while $40.2 \%$ of them answered „no“. In the second part we tried to find out whether the respondents were aware of the two specific environmental labels which are used in the Slovak market. $51.7 \%$ of them know the label „Environmentally friendly product“ andn $19.3 \%$ of them know the label „Ecolabel“. It is worth saying that up to $29 \%$ of respondents do not know any of the mentioned environmental labelling. There is certainly a gap to be filled in terms of awareness towards environmental product labelling.

Furthemore, we looked into the factors which influence the respondents in their purchasing decisions regarding particular products. In course of product selection, consumers mostly notice quality (85\%), then the product price $(72 \%)$ and only afterwards its mark referring to particular quality perception $(32 \%)$. Only then they take into consideration other product features, such as operating costs $(40 \%)$, the material the product is made of $(18 \%)$ or the possibility of ecological waste disposal (14\%) and the others.

The marketing communication as stated by Č́byová, Ptačin [6], Kollárová [11], or even Rajčák [7] plays a crucial role while promoting product innovations. Eco innovation products are not an exception because thanks to its tools, the product awareness of consumers grows. The research showed that Slovak consumers did not have enough information on ecological products. Up to $72 \%$ of them declare themselves to be insufficiently informed on the products and only $7 \%$ of the respondents think to have enough information. In order to improve the conditions, it is crucial to make good use of various communication tools. One of the solutions is to combine classic forms of marketing communication with the digital ones, which are more environmental friendly and economical. Combining offline and online (or digital) communication enable businesses to launch new products/services or information on implemented innovations as particular forms can function a complement to one another.

The media also play a key role in the process of raising consumer awareness $[12,13]$. However, as stated by Petranová [8], media literacy of consumers is not the same - for example, it may be quite low in case of the elderly. The research showed that the respondents did not have enough information, only $4.2 \%$ of them expressed satisfaction with the information the media provide them with. The most commonly used sources of information are the Internet $(53.76 \%)$ and TV $(39.16 \%)$, the smallest amount is provided by regional newspapers $(3.54 \%)$.

\section{Conclusion}

By way of ecological innovations, businesses are trying to contribute to improving the present state of the polluted environment or promote sensible exploitation of sources, which is a reliable sign of a positive change to their thinking, philosophy or eventually a business strategy.

Businesses are getting more and more exposed to demanding requirements from the part of their consumers and even competitors. The technological development is going at a high speed and doing business is becoming global. In order for the company to be able to keep pace with the top, it has to pay attention to the field of innovations, which means continuously bringing forward new ideas, elaborating an innovative communication policy, which shall be perpetually developed and adapted to up-to-date trends.

The field of innovations is highly dynamic as it is influenced by various trends and fashions. Our research also showed that Slovak businesses were more and more interested in eco innovations as they are aware of their high importance in doing business. As a result, it is important to make efforts not only in their creation, and implementation but also in the process of promotion and marketing. That's where marketing communication with is tools play a mojor role.

New trends in the on-line marketing point to growing tendancy to use on-line marketing campaigns and on-line marketing communication tools. Up-to-date technological tools are being perpetually developed in order to monitor activities in social networks. Thanks to new features of smart phones, mobile marketing has started being used as a basis for new applications, such as localisation services or customized mobile applications. Tablettes have become a strong and perspective sales channel. Advertising companies are implementing more and more customized content of e-mail campaigns while making use of localisation applications integrated in smart phones and tablettes in order to actively 
target larger groups of consumers taking into consideration their present geographical position.

\section{Acknowledgement}

The paper is a part of research project VEGA 1/0640/15 named: "Phygital Concept and Its Use in Sustainable Integrated Environmental Management of Businesses".

\section{References}

[1] Arundel, A., Kemp. R., Measuring Eco-innovation, (Working Paper Series), United Nations University: Maastricht Economic and Social Research and Training Centre on Innovation and Technology, 2009, 40 p.

[2] "OECD and Statistical Office of the European Communities (Eurostat),“ Oslo Manual: Guidelines for Collecting and Interpreting Innovation Data, $3^{\text {rd }}$ ed., OECD: Paris, 2005, 166 p. ISBN 978- 92-6401308-3

[3] Rusko, M., "Environmentálne značky používané v rámci environmentálneho označovanie typu I.,“" Magazín prepriemyselnú ekológiu XXI. storočia, vol. VIII, issue 4, Bratislava: Envira, pp. 22-23, 2005-2006, ISSN 1335-874X. Available <http://www.envira.sk/04_05_21/znacky.pdf>

[4] "ISO 14001:2004"

[5] "Environmentálne označovanie produktov," online, Available at: $<\mathrm{http} / / / \mathrm{www}$.enviroportal.sk/environmentalne-temy/starostlivost-ozp/dobrovolne-nastroje-environmentalnej-politiky/environmentalneoznacovanie-produktov>

[6] Č́ayová, L., Ptačin, J., "Benchmarking Comparison of Marketing Communication of Universities in Slovakia," Communication Today, vol. 5, issue 1, pp 55-69, 2014. ISSN 1338-130X
[7] Rajčák, M., Marketingová komunikácia $v$ digitálnom veku: Vybranétrendy, metódy a techniky, Trnava: Fakulta masmediálnej komunikácie UCM, 2013, 102 p. ISBN 978-80-8105-523-2

[8] Petranová, D., "Media education in the life of senior population," European Journal of Science and Theology, vol. 9, issue 2, pp. 1324, 2013. ISSN 1841-0464

[9] Bezáková, Z., "Nástroje na podporu zvyšovania ekoinovačnej výkonnosti," Otvorený inovačný proces: Podpora širenia vedomostí a vytvárania hodnôt $v$ podnikatel'ských subjektoch, Trnava: Fakulta masmediálnej komunikácie UCM, 2014, pp. 35-41. ISBN 978-80-8105$615-4$

[10] Grib, L., "Integrovaná marketingová komunikácia v kontexte komercializácie inovácií," Otvorený inovačný proces: Podpora šírenia vedomostí a vytvárania hodnôt v podnikatelských subjektoch, Trnava: Fakulta masmediálnej komunikácie UCM, 2014, pp. 89-96. ISBN 978-80-8105-615-4

[11] Kollárová, D., “„Mysli globálne, konaj lokálne” pre slovenských importérov automobilov neplatí," Communication Today, vol. 4, issue 1, pp. 95-105, 2013. ISSN 1338-130X

[12] Pravdová, H., Radošinská, J., "Media culture in the context of transformation of contemporary spiritual values and spirituality," European Journal of Science and Theology, vol. 9, issue 6, pp. 169178, 2013. ISSN 1841-0464

[13] Solík, M., Višňovský, J., Laluhová, J., "Media as a tool for fostering values in the contemporary society," European Journal of Science and Theology, vol. 9, issue 6, pp. 71-77, 2013. ISSN 841-0464

[14] Zaušková, A., Miklenčičová, R., Madleňák, A., Bezáková, Z., Mendelová, D., "Environmental protection and sustainable development in the Slovak republic," European Journal of Science and Theology, vol. 9, issue 6, pp. 153-159, 2013. ISSN 1841-0464 